\title{
Quantitation of a slide test (Monotest) for infectious mononucleosis
}

\author{
P. KENNETH CARTER ${ }^{1}$, IRWIN SCHOEN, AND TERU MIYAHIRA \\ From the Division of Pathology, Cedars-Sinai Medical Center, Mount Sinai Hospital Division, \\ Los Angeles, and Student Health Service Clinical Laboratory, University of California at \\ Los Angeles, California, USA
}

SYNOPSIS A slide test for infectious mononucleosis using formalinized horse erythrocytes (Monotest ${ }^{2}$ ) was quantitated and compared with standard differential heterophile (Davidsohn) titres performed on the same specimens. The Monotest titre parallels the standard presump- $\stackrel{\mathbb{\Phi}}{-}$ tive heterophile (antisheep cell) titre in the degree of elevation, with a ratio of Monotest $\vec{\omega}$ to heterophile titre of approximately 1 to 56. The simplicity of the quantitative slide test $\bigcirc$ recommends it as a routine test for infectious mononucleosis.

A number of new slide tests using horse erythrocytes for infectious mononucleosis have recently been introduced. These have been shown to have a high degree of sensitivity and specificity, whether the horse erythrocytes are citrated (Monospot, Ortho) (Lee, Davidsohn, and Panczyszyn, 1968) or formalin-treated (Monotest) (Hoff and Bauer, 1965; Davidsohn, 1967; Sinay, Schoen, and Miyahira, 1968; Lowell and Kazakaitis, 1969). None has mentioned quantitation of the test, and we elected to compare quantitations of the Monotest with standard differential heterophiles performed on the same serum samples.

\section{Methods}

Doubling dilutions of patients' sera in saline were prepared using $0.25 \mathrm{ml}$ volumes of serum and saline and a single $1 \mathrm{ml}$ plastic disposable pipette. The Monotest was then performed according to the instructions of the manufacturer. A drop of serum dilution and a drop of Monotest reagent were mixed on a glass slide and gently rotated for two minutes. A coarse 4 + agglutination was considered positive.

Received for publication 13 February 1970.

1 Please send requests for reprints to Dr Carter at Mount Sinai Hospital.

Monotest, Wampole Laboratories.
No agglutination or a finely granular pat-苂 tern was considered negative. Any pattern be- $\varrho$ tween these two was considered weakly reactive $\vec{O}$ $(1+, 2+$, or $3+)$. It was found that the last 3 tubes in a titration proceeded from positive to negative in a manner similar to quantitative? VDRLs, that is, usually after the last positive tube there was a weakly reactive tube followed? by negative tubes. The titre was arbitrarily chosen as the last tube showing at least a $2+\delta$ agglutination. The tests were performed at ran- $\bar{\beta}$ dom intervals from November 1968 to Mayo 1969, using Monotest batch numbers 58, 64, $66,67,68$, and 69 . The differential heterophile tests were performed the same day as the Monotest, using the well known standard method of $N$ Davidsohn and Nelson (1969).

The sera studied included hospital specimens $N$ submitted for infectious mononucleosis serology ${ }_{\sigma}^{\omega}$ at Mount Sinai Hospital; specimens from students presenting at UCLA Student Health Service? with symptoms suggestive of mononucleosis; aœ few specimens from Loma Linda University Clinical Laboratory; and two commercial specimens of desiccated positive control sera, re-बत्ब hydrated according to the manufacturers' direc- $\frac{}{\mathrm{D}}$ tions (Hyland, BBL). The patients' sera were all tested within 24 hours or were frozen within 24 hours of collection and thawed immediatelyo before testing.

No attempt was made to correlate the results 


\begin{tabular}{rlcrcr}
\hline No, of Specimens & Monotest Titre & \multicolumn{2}{l}{ Differential Heterophile Titre } \\
\cline { 2 - 4 } & & Sheep Cell & Guinea-pig Kidney \\
\hline 23 & Neg. & 14 & 0 & 7 \\
7 & $1: 1$ & 28 & 14 & 0 \\
9 & $1: 2$ & 112 & 56 & 0 \\
9 & $1: 4$ & 224 & 224 & 14 \\
21 & $1: 8$ & 224 & 224 & 0 \\
22 & $1: 16$ & 448 & 896 & 0 \\
27 & $1: 32$ & 896 & 1792 & 7 \\
5 & $1: 64$ & 1792 & 3584 & 14 \\
2 & $1: 128$ & 3584 & 3584 & 56 \\
1 & $1: 256$ & 1792 & 28
\end{tabular}

Table I Comparison of quantitative Monotest and differential heterophile titres in 126 specimens from patients

${ }^{1}$ Reciprocal of most frequent titre value.

of the tests with the clinical status of the patients; our primary consideration was a comparison of the quantitative slide test with the titres of the standard method of Davidsohn and Nelson (1969).

All of the sera were inactivated at $56^{\circ} \mathrm{C}$ for 30 minutes before testing.

When performing differential heterophiles, we routinely use as reagent controls a positive control mononucleosis serum and a negative control commercial 'Forssman antibody' (serum sickness) serum. The latter is used to demonstrate the ability of the guinea pig antigen reagent to absorb heterophile antibodies other than those of infectious mononucleosis. Several lots of such commercial 'negative control' sera were included in the Monotest/Davidsohn comparison, and because of results to be described, the negative control sera were also tested with the Monospot test, performed according to the manufacturers' instructions (Monotest batch no. 73, Monospot batch no. IM-161).

\section{Results}

Table I presents a summary of the results. In all cases the Monotest and differential heterophile titres agreed regarding the diagnosis.

The most significant finding is that the Monotest titre generally parallels the heterophile titre. Comparison of the Monotest titre with the presumptive heterophile (antisheep cell) titre reveals a ratio of approximately 1 to 56 , that is, the Monotest titre multiplied times 56 approximately equals the sheep cell titre. This value is selected, although the correlation is not perfect at all high and low titres, to enable an easy comparison of the Monotest titre values with the well known Davidsohn titre values, such that the approximate equivalent Davidsohn titre value may be reported to the physician as well as the Monotest titre, if desired.

Most of the heterophile titres were clustered about a most frequent titre +1 dilution at each level of Monotest titre, both for the unabsorbed sheep cells and after absorption with guineapig kidney and beef erythrocytes. In only three instances was any titre more than two dilutions from the most frequent titre. Each of the three patients had differential test titres concordant with the Monotest result.

Table II details the 'weakly reactive' Mono- $\vec{\omega}$ test reactions of undiluted $(1: 1)$ sera observed in seven of the 126 patients. None of these seven undiluted (1:1) sera showed a 4+ reaction. Results cannot be adequately interpreted, as the clinical state of the patients was not studied in depth. However, it is apparent that occasional $\stackrel{\circ}{\mathbb{D}}$ 'doubtful' reactions occur, as in previous studies, $\varrho$ suggesting that the test be repeated later to demonstrate a rising (or falling) titre (Sinay et al, 1968).

\begin{tabular}{lllll}
\hline $\begin{array}{l}\text { Mono- } \\
\text { test }\end{array}$ & $\begin{array}{l}\text { Hetero- } \\
\text { phile }\end{array}$ & $\begin{array}{l}\text { Guinea-pig } \\
\text { Kidney }\end{array}$ & Beef RBC & $\begin{array}{l}\text { Davidsohn } \\
\text { Interpretation }\end{array}$ \\
\hline $3+$ & $1: 28$ & 0 & $1: 7$ & Neg. \\
$2+$ & $1: 28$ & $1: 28$ & 0 & Pos. \\
$3+$ & $1: 56$ & $1: 14$ & $1: 7$ & Pos. \\
$3+$ & $1: 56$ & $1: 28$ & $1: 14$ & Neg. \\
$2+, 1+$ & $1: 14$ & 0 & 0 & Neg. \\
$3+$ & $1: 28$ & $1: 14$ & 0 & Pos. \\
$2+$ & $1: 28$ & $1: 14$ & 0 & Pos. \\
\hline
\end{tabular}

Table II 'Weakly reactive' Monotests

Atypical beef cell absorption perha ps due to decreased anti- $N$ genicity of the beef erythrocytes.

Results of the 'negative control' sera and two N batches of 'positive control' commercial sera are listed in Table III.

Both the Monotest and the Monospot tests were in agreement with the differential hetero- + ? phile interpretation using these sera, with one 7 exception. The BBL serum sickness control serum, which was negative for Monospot and $\stackrel{\mathbb{\perp}}{\circ}$ Davidsohn tests, revealed a fairly strong agglu- $-\mathbb{Q}$ tination with Monotest $(1: 2$ and $1: 4$, with two batches of the control serum). The reason for this is unexplained and warrants further study, as it may represent decreased specificity of the Monotest formalinized horse cells. 


\begin{tabular}{|c|c|c|c|c|c|c|c|}
\hline Batch No. & Control Serum & $\begin{array}{l}\text { Mono- } \\
\text { spot }\end{array}$ & Monotest & $\begin{array}{l}\text { Pre- } \\
\text { sumptive }\end{array}$ & $\begin{array}{l}\text { Guinea- } \\
\text { pig Kidney }\end{array}$ & $\begin{array}{l}\text { Beef } \\
R B C\end{array}$ & $\begin{array}{l}\text { Davidsohn } \\
\text { Interpretation }\end{array}$ \\
\hline $\begin{array}{l}1518320 \\
804174 \\
9041701 \\
9051711 \\
8031731 \\
9051721 \\
528219\end{array}$ & $\begin{array}{l}\text { Difco infectious mononucleosis-positive serum } \\
\text { BBL positive control serum } \\
\text { BBL serum sickness control serum } \\
\text { BBL serum sickness control serum } \\
\text { BBL high titre heterophile normal serum } \\
\text { BBL high titre heterophile normal serum } \\
\text { Difco heterophile Forssman antiserum }\end{array}$ & $\begin{array}{l}\text { Pos. } \\
\text { Pos. } \\
\text { Neg. } \\
\text { Neg. } \\
\text { Q.N.S. } \\
\text { Neg. } \\
\text { Neg. }\end{array}$ & $\begin{array}{l}\text { Pos. }(1: 16) \\
\text { Pos. }(1: 8) \\
\text { Pos. }(1: 2) \\
\text { Pos. }(1: 4) \\
\text { Neg. } \\
\text { Neg. } \\
\text { Neg. }\end{array}$ & $\begin{array}{l}1: 448 \\
1: 224 \\
1: 28 \\
1: 28 \\
1: 56 \\
1: 56 \\
1: 56\end{array}$ & $\begin{array}{l}1: 224 \\
1: 112 \\
0 \\
0 \\
0 \\
0 \\
0\end{array}$ & $\begin{array}{l}0 \\
0 \\
0 \\
0 \\
1: 56 \\
1: 112 \\
1: 28\end{array}$ & $\begin{array}{l}\text { Pos. } \\
\text { Pos. } \\
\text { Neg. } \\
\text { Neg. } \\
\text { Neg. } \\
\text { Neg. } \\
\text { Neg. }\end{array}$ \\
\hline
\end{tabular}

Table III Slide tests for mononucleosis and Davidsohn differential test with commercial reagent control sera $\stackrel{\odot}{\varrho}$

\section{Discussion}

For diagnostic problems that may be resolved by demonstration of rising titres, or occasionally falling titres, the quantitation of infectious mononucleosis serology could be significant. Many clinicians request quantitations of titre as an aid to management of the patient, eg, when to send the patient back to school. Previously, the recommendation has been made that when the Monotest is positive the quantitative differential absorption test might be necessary 'for obtaining titres of positivity when these are required for comparative purposes' (Davidsohn, 1967). The simplequantitation of the Monotest described here appears to be equally satisfactory if such comparative data are requested.

The results in our series indicate an apparent sensitivity and specificity of a degree similar to previous reports. As a result of these studies we now routinely perform only the Monotest, and, if positive, quantitate the specimen. We report the Monotest titre and the approximately equivalent presumptive Davidsohn (antisheep cell) titre. The differential test is reserved for special instances, as for example when the clinical status of the patient is discordant with the Monotest result, or serum sickness is considered in the differential $\overrightarrow{\vec{\omega}}$ diagnosis.

No attempt was made to test the sera withouto inactivation because of previous experience showing occasional false-negative reactions on 0 unheated sera (Sinay et al, 1968). Other investi- ָे gators are also inactivating their test sera (Lowello and Kazakaitis, 1969). The directions for Mono-. test state that the test may be performed on fresh $\vec{z}$ or inactivated serum.

References

Davidson, R. J. L. (1967). New slide test for infectious mono- $\vec{\theta}$ nucleosis. J. clin. Path., 20, 643-646.

Davidsohn, I., and Nelson, D. A. (1969). Immunohematology. Infectious mononucleosis, 280-292. Serologic tests, 284-290. In Todd-Sanford Clinical Diagnosis by Laboratory Methods, 14th ed., edited by I. Davidsohn and J. B. Henry. Saunders, Philadelphia.

Hoff, G., and Bauer, S. (1965). A new rapid slide test for infec-? tious mononucleosis. J. Amer med. Ass., 194, 351-353.

Lee, C. L., Davidsohn, I., and Panczyszyn, O. (1968). Horse@ agglutinins in infectious mononucleosis-II. The spot test. Amer. J. clin. Path., 49, 12-18.

Lowell, D. M., and Kazakaitis, M. (1969). Evaluation of a rapidslide test for the diagnosis of infectious mononucleosis. Amer. J. med. Technol., 35, 233-238.

Sinay, H. S., Schoen, I., and Miyahira, T. (1968). A heat-labile inhibitor in human serum with the horse red blood celt agglutination test (Mono-test) for infectious mononucleosis. Amer. J. clin. Path., 50, 75-82. 